\title{
EM BUSCA DA UNIDADE PERDIDA
}

\author{
SUELY CORVACHO
}

Centro Federal de Educação Tecnológica de São Paulo

\section{Resumo}

$\mathrm{O}$ artigo pretende explorar aspectos psíquicos presentes em São Bernardo, segundo romance de Graciliano Ramos. A análise de duas relações do protagonista, uma bem-sucedida com seu capataz e outra frustrada com a esposa, permite perceber sua forma de se apropriar do traço do outro. Para a leitura, foram necessários conceitos da psicanálise, da filosofia da linguagem e dados concernentes à história contemporânea do Brasil, numa perspectiva integradora.

Palavras-chave

Graciliano Ramos; São Bernardo; psicanálise; processo de identificação.

\begin{abstract}
This article seeks to explore aspects of the psychic dimension present in São Bernardo, Graciliano Ramos's second novel. The analysis of the protagonist's two relationships - one, successful, with his foreman, the other a frustrated relationship with his wife - allows us to identify his means of appropriating the other's trace. For this reading, concepts from Psychoanalysis and the Philosophy of Language, as well as data regarding contemporary Brazilian history, are used, in an integrated perspective.
\end{abstract}

Keywords

Graciliano Ramos; São Bernardo; psychoanalysis; process of identification.

$\mathrm{Na}$ fortuna crítica de Graciliano Ramos, encontram-se várias leituras que procuram integrar, com perspicácia, elementos sociais, estilísticos, psíquicos e históricos presentes em São Bernardo (1934). Contudo, a abordagem da dimensão psíquica enfoca frequientemente elementos pontuais do romance: a escolha de Madalena, a emergência do ciúme, a necessidade de escrever o livro, o ressentimento do protagonista, entre outros. O intuito deste artigo é, então, procurar desenvolver a idéia de que há relações de complementação entre alguns desses aspectos. Para tanto, buscaremos nos valer de uma perspectiva algo integradora, articulando conceitos da psicanálise, sob o prisma freudiano; noções da filosofia da linguagem, sob o ângulo de Bakhtin; além de dados da história contemporânea do Brasil.

O romance inicia in media res com o protagonista, Paulo Honório, tentando escrever um livro, segundo o método da divisão do trabalho. Frustrada a tentativa, assume sozinho a tarefa e começa a narrar suas memórias. Apresenta rapidamente sua infância e juventude; mais devagar, a aquisição da fazenda São Bernardo e os sucessivos melhoramentos; e demoradamente, a união com Madalena. O texto se estende, porque o narrador descreve, com detalhes, o primeiro encontro, o casamento, as cenas de ciúme e a morte da esposa.

A distribuição dos capítulos é tão desigual que o leitor se pergunta: por que o fazendeiro traça o perfil da esposa com maior apuro do que o processo de acúmulo de bens e lhe reserva tanto espaço no livro de memórias? Por que o título do romance não evoca, então, esse interesse, mas outro, a fazenda? A paradoxal atitude não começa aí; na verdade, desde o momento em que a personagem principal resolve escolher uma esposa, já se percebe de modo claro que o critério econômico nem sempre predomina. 
No início, o narrador tende a escolher Marcela para ser a mãe do herdeiro de São Bernardo. O casamento com a filha do juiz lhe interessa, pois viabiliza simultaneamente dois projetos: gerar o herdeiro desejado e anexar as únicas terras limítrofes ainda não invadidas. Depois, contrariando seus interesses econômicos, Paulo Honório elege Madalena: "Precisamente o contrário da mulher que andava imaginando - mas agradava-me, com os diabos" (São Bernardo, p. 67). ${ }^{171}$

A rigor, entretanto, é falacioso considerar que essa seja a primeira situação em que o aspecto mercantil cede lugar a outro. Muito antes do casamento, o protagonista já traz para o interior da fazenda pessoas pouco ou quase nada afinadas com sua ideologia, como Margarida e Sr. Ribeiro. Contrata o guarda-livros segundo o critério da simpatia e não da eficiência. Esses e outros exemplos levam-nos a crer que existe um funcionamento psíquico de união com outras pessoas que não se orienta necessariamente pelo desejo da acumulação de capital. É esse funcionamento que pretendemos apreender, examinando a primeira e a última pessoa a ser introduzida em São Bernardo, Casimiro Lopes e Madalena, respectivamente.

Casimiro Honório: a unidade conquistada

Em suas andanças pelo sertão, ${ }^{172}$ Paulo Honório se liga a Casimiro Lopes, homem violento e obediente. Mais do que braço direito, o jagunço torna-se peça fundamental para a conquista dos bens materiais. No início da "carreira", graças a ele, o protagonista consegue reaver o dinheiro de uma transação quase perdida com Dr. Sampaio, e, depois, graças a ele também, consegue expandir os limites da fazenda. Com o passar do tempo, a afinidade é tamanha que passam a se comunicar sem palavras: [Paulo Honório] "Isto vai mal, Casimiro, dizia eu com os olhos. Casimiro Lopes concordava, erguendo os ombros" (São Bernardo, p. 151). Na óptica do protagonista, ambos compõem uma unidade, conforme se pode notar na passagem em que Madalena o acusa de assassino:

Ainda em cima ingrata. Casimiro Lopes levava o filho dela para o alpendre e embalava-o, cantando, aboiando. Que trapalhada! que confusão! Ela não tinha chamado assassino a Casimiro Lopes, mas a mim. Naquele momento, porém, não vi nas minhas idéias nenhuma incoerência. E não me espantaria se me afirmassem que eu e Casimiro Lopes éramos uma pessoa só. (São Bernardo, p. 143)

A unidade aventada por Paulo Honório pode ser compreendida à luz do que Freud, em "Psicologia de grupo e a análise do ego", desenvolveu desenvolveu sobre processo de identificação no interior de grupos. ${ }^{173}$ Segundo o estudioso, a relação dos membros de um grupo com o seu líder não está assentada somente na ambição de ser o outro, mas, sobretudo, na possibilidade de os componentes do grupo projetarem no "líder" os traços a que aspiram em si mesmos (o ideal de ego ${ }^{174}$ ). No fragmento, Graciliano Ramos apresenta-nos o reverso

\footnotetext{
${ }^{171}$ Todas as citações de São Bernardo provêm da seguinte edição: Graciliano Ramos, São Bernardo, Rio de Janeiro, Record, 1997, $67^{\mathrm{a}}$ ed.

${ }^{172}$ Alguns aspectos do capítulo foram apresentados no XI Encontro Regional da Abralic - Literatura, artes, saberes, 2007, na comunicação intitulada "O ciúme em São Bernardo".

${ }^{173}$ Ainda que Freud abandone, quase completamente, as formulações sobre o processo identificatório na fase adulta, para se concentrar nos primeiros anos de vida da criança e, com isso, chegue à noção de superego, mantivemos o conceito tal como formulado inicialmente, porque é operacional para iluminar o texto.

${ }^{174}$ Ideal de ego é o conceito criado por Freud para justificar, entre outras, a submissão ao líder. Em suas palavras: "Em ocasiões anteriores, fomos levados à hipótese de que no ego se desenvolve uma instância assim, capaz de isolar-se do resto daquele ego e entrar em conflito com ele. A essa instância chamamos de 'ideal do ego' e, a título de funções, atribuímos-lhe a auto-observação, a consciência moral, a censura dos sonhos e a principal influência na repressão. Dissemos que ele é o herdeiro do narcisismo original em que o ego infantil desfrutava de auto-suficiência; gradualmente reúne, das influências do meio ambiente, as exigências que este impõe ao ego, das quais este não pode sempre estar à altura; de maneira que um homem, quando não pode estar
} 
da medalha: um "líder" que, no processo de identificação, introjeta os traços de seu "liderado".

Não é a primeira vez que o escritor recorre ao mecanismo para expor as relações de trabalho. Em seu primeiro romance, Caetés, o autor explora a identificação de João Valério, protagonista, com o patrão; em São Bernardo, apresenta o inverso, ou seja, a forma pela qual o patrão se apropria dos traços do empregado e os introjeta. Desse modo, o líder, Paulo Honório, potencializa a violência, quando, no plano imaginário, assume a do capataz como extensão da sua e, com isso, consegue expandir seus limites externos.

Convém sublinhar que tal identificação, construída ao longo de anos, vem selada por uma visão de mundo compartilhada. $O$ jagunço, por exemplo, rechaça as idéias socialistas de Padilha, alegando que "as coisas desde o começo do mundo tinham dono" (São Bernardo, p. 58); Paulo Honório, por sua vez, não titubeia em declarar que poria seu nome na capa do romance, escrito segundo a divisão de trabalho. Portanto, empregado e patrão adotam um mesmo ponto de vista: naturalizam a propriedade privada.

Essa união, forjada no sertão, consolidada durante a conquista e expansão da fazenda, não se abala nem mesmo quando o protagonista resolve mudar seus planos e passa a compor o livro. Nos capítulos dedicados a expor os bastidores da produção literária (2, 19 e 36), o leitor observa a cena recorrente: o narrador sentado à mesa de jantar, fumando cachimbo e bebendo café, enquanto Casimiro Lopes se faz presente, ora pergunta se falta algo ora acocora-se ao pé da janela ora dorme.

Se, para o protagonista, a união com Casimiro Lopes expressa afinidade psíquica e ideológica, a mesma relação, nas mãos do autor, ${ }^{175}$ é expressão histórica. Para ligar uma dimensão à outra, uma informação é apresentada: "Afinal, cansado daquela vida de cigano, voltei para a mata. Casimiro Lopes, que não bebia água na ribeira do Navio, acompanhou-me" (São Bernardo, p. 14).

Segundo Leonardo Gominho, ${ }^{176}$ em Ribeira do Navio, município de Pernambuco, nasceu e viveu Casimiro Honório, um dos mais conhecidos cangaceiros que dominaram o Nordeste no final do século XIX e início do XX. Dono de fazendas e criador de gado bovino, caprino, ovino e eqüino, Casimiro Honório da Silva era considerado "chefe de polícia" e "juiz de Direito" em sua região. Ganhou notoriedade porque vingava injúrias próprias, dos parentes, dos amigos e até mesmo de estranhos, desde que reconhecesse situação de injustiça. ${ }^{177}$ Depois de muitas lutas, uma delas, aliás, com Virgulino Ferreira da Silva, o Lampião, Casimiro morre em 1921, vítima de uma infecção, causada por um acidente banal.

satisfeito com seu próprio ego, tem, no entanto, possibilidade de encontrar satisfação no ideal do ego que se diferenciou do ego" - cf. "Psicologia de grupo e análise do ego", in Obras psicológicas completas, Rio de Janeiro, Imago, 1996, vol. XVIII, p. 119.

${ }^{175}$ Aqui, autor é concebido segundo a noção bakhtiniana expressa em "O problema do herói na atividade estética”. Não se confunde o autor-homem, componente da vida, e autor-criador, componente da obra, pois o primeiro é sujeito de sua vida, ora potente ora impotente, e o segundo, sujeito de sua obra, onipotente. As mesmas idéias, ao serem expressas em instâncias diferentes - na vida e na obra - assumirão funções específicas, pois em cada instância rege um princípio produtor próprio - o da obra é o princípio criador. A confusão entre autor-homem e autor-criador provoca, para Bakhtin, "de um lado, a ignorância e a distorção da pessoa ética, biográfica, do autor, e, do outro lado, uma incompreensão geral do todo constituído pela obra e o autor" - cf. Mikhail Bakhtin, Estética da criação verbal, São Paulo, Martins Fontes, 2000, p. 31.

176 Leonardo Ferraz Gominho, Floresta: uma terra - um povo, disponível em http://br.geocities.com/leonardogominho/floresiv1.doc, acessado em em 25.07.2007.

${ }^{177}$ Conforme sua crônica "Dois cangaços", Graciliano Ramos desconfia do caráter romântico atribuído aos cangaceiros antigos, como Casimiro Honório: "Lampião era um monstro, tornou-se um monstro, símbolo de todas as monstruosidades possíveis. Resta, porém, saber se os outros, os antigos, não praticavam ações como as dele e se não havia qualquer interesse em escondê-las. Talvez houvesse. Casimiro Honório, os Morais, Jesuíno Brilhante e Antônio Silvino tinham alguma coisa que perder, terra ou fazenda, pelo menos um nome, valor tradicional. Não podiam mostrar-se de repente demolidores de instituições respeitadas: precisavam mantê-las, apesar de réprobos, eram de alguma forma elementos de ordem, amigos da propriedade, de todos os atributos da propriedade. O que eles combatiam era, não a propriedade em si, mas a propriedade dos seus inimigos. Daí 
Em suma, o autor espalha alguns elementos no romance, para que o leitor chegue ao cangaceiro: o sentimento de unidade, aventado pelo protagonista, permite a união - Casimiro Honório - e a locução "Ribeira do Navio" informa a origem do cangaceiro. Logo, o autor compõe duas personagens ficcionais - o fazendeiro e o jagunço - dividindo os traços do "fazendeiro-cangaceiro" no qual se inspirou e oferece índices suficientes para que o leitor possa fazer a síntese e compreender que o perfil de Paulo Honório evoca a personagem histórica. Estabelecido o liame, o leitor deve continuar desenrolando o fio narrativo, pois o autor tem mais a revelar.

Com a pomicultura e a avicultura, Paulo Honório começa a construir uma estrada de rodagem, com o fim de levar as mercadorias ao mercado. Azevedo Gondim escreve dois artigos elogiando a iniciativa, e a compara com a de dois empresários: "chamou-me patriota, citou Ford e Delmiro Gouveia" (São Bernardo, p. 40). Para entender o elogio, convém lembrar que, na década de 1920, Henry Ford, refém do monopólio inglês de borracha, resolve investir no Brasil. Com o intuito de realizar seu sonho de produzir meio milhão de toneladas de látex/ano, o americano recebe do governo paraense cerca de um milhão de hectares de terras, onde planta os seringais e constrói uma vila: Fordlândia. ${ }^{178}$ No local, os trabalhadores e os seringais são rigidamente controlados. O tempo e a qualidade de produção são fiscalizados, assim como o comportamento social e os atos mais corriqueiros dos funcionários. Todas as formas de controle têm um mesmo objetivo: impor a racionalização do trabalho e criar um perfil de trabalhador, mais adequado aos moldes capitalistas.

Delmiro Gouveia, por sua vez, apresenta uma trajetória bastante próxima à do protagonista. De origem pobre, o empresário começa a trabalhar cedo como bilheteiro de estação de trem, consegue acumular seu primeiro capital, no sertão, comercializando peles de cabras e bodes. Mais tarde, em 1899, diversifica as atividades: assume a direção da Usina Beltrão e inaugura o Mercado Derby, na capital pernambucana. O sucesso vem acompanhado por problemas sérios, conforme afirma Graciliano Ramos em sua crônica "Recordações de uma Indústria Morta":

A fortuna repentina lhe proporcionou inimigos fortes. Os colegas apertaram-no, a política interveio na briga, interesses públicos relacionaram-se com melindres de família. Gouveia desacatou um cidadão poderoso ${ }^{179}$ e fugiu, largando bens aos credores, que tiveram prejuízo de mais de noventa por cento. ${ }^{180}$

Em 1903, o comerciante compra uma fazenda em Pedra, pequeno povoado às margens da Ferrovia Paulo Afonso, sertão de Alagoas, onde constrói uma usina elétrica, uma fábrica de linhas de costura e um núcleo fabril, com cerca de 250 casas e infra-estrutura. Procura administrar com precisão e rigor a vida do operário, de forma a torná-lo o mais produtivo possível. O sucesso do projeto é garantido por medidas que vão de prêmios a

\footnotetext{
talvez surgirem conservadores, poetizados e aumentados na literatura branca do Nordeste" - cf. Graciliano Ramos, Viventes das Alagoas, Rio de Janeiro, Record, 1979, p. 147.

${ }^{178}$ Conforme Vianna Moog, "Eles vão levar uma cidade desarmada, mas pronta, como se se tratasse de automóveis saídos das linhas de montagem da Ford Motor Company: casas, hospitais, cafeterias, drugstores, cimento, areão para as canchas de tênis, aparelhos sanitários, bulldozers, serraria, uma cidade completa por armar" - cf. Vianna Moog, Bandeirantes e pioneiros, Rio de Janeiro, Civilização Brasileira, 1966, p. 22.

${ }^{179}$ Em outras palavras, em 1899, Delmiro envolve-se em conflitos políticos com o então prefeito de Recife, Esmeraldino Bandeira, político de confiança de Francisco de Assis Rosa e Silva, senador e vice-presidente da República, o que lhe acarreta várias dificuldades comerciais. No segundo semestre do mesmo ano, procura o vice-presidente no Rio de Janeiro, para que ele interceda a seu favor. O pedido não só é rejeitado como termina de forma desastrosa: Delmiro agride o senador com a bengala. $\mathrm{O}$ caso ganha repercussão nacional e resulta, conforme Telma de Barros Correia, "no incêndio do Mercado do Derby pela polícia, na inviabilização da Usina Beltrão e da própria permanência de Delmiro no Estado" - cf. Telma de Barros Correia. Pedra: plano e cotidiano operário no sertão, Campinas, Papirus, 1998, p. 188.

${ }^{180}$ G. Ramos, Viventes das Alagoas, op. cit., p. 114.
} 
castigos corporais, tudo com o aval do governo de Alagoas e apoio de seus vigias e capangas. Ainda que não haja notícias de assassinatos ordenados pelo fazendeiro, há vários relatos de espancamentos e de torturas - como a de amarrar os operários no "tronco", uma lembrança escravocrata que o empresário fazia questão de preservar. Curiosamente, mesmo com toda a violência, Pedra foi concebida por intelectuais da época como "ação exemplar na eliminação de obstáculos à penetração do progresso no Sertão". ${ }^{181}$

A iniciativa de Ford e a de Delmiro Gouveia guardam semelhanças entre si no que concerne à divisão do trabalho, aos métodos de controle e à "contribuição patriótica". Motivos de exemplo para o dono de São Bernardo transformam-se em elementos de denúncia para o autor. A associação é simples: se as práticas do protagonista evocam as de Casimiro Honório, fazendeiro-cangaceiro; se as iniciativas do protagonista remetem às dos empresários modernos - Ford e Delmiro Gouveia - , logo, as práticas dos empresários modernos remetem às de Casimiro Honório. Com isso, evidencia-se que, ao contrário de outros intelectuais que viram em Pedra e Fordlância exemplos de superação do atraso brasileiro, o autor os considera práticas de um capitalismo moderno, que alia os já conhecidos elementos de exploração a atos de violência só encontrados nas relações escravocratas; desse modo, cria uma nova síntese para descrever a realidade brasileira: "capitalismo-cangaceiro".

Ainda que com funções diferentes, pode-se afirmar que, no romance, a ligação entre Paulo Honório e Casimiro Lopes é bem-sucedida, pois traz tranqüilidade ao narrador, e permite que o autor denuncie as condições do país. No entanto, a rigor, é perigoso afirmar que "a unidade" se consolida e a busca se encerra, uma vez que, do ponto de vista psíquico, o preenchimento da falta, objeto inapreensível do desejo, é impossível. Além disso, o mecanismo de identidade projetiva pode trazer a tranqüilidade, mas, às vezes, ocasiona o contrário, a inquietude: é o que se observa na relação com Madalena.

Madalena - a unidade perdida

$\mathrm{Na}$ escolha da esposa, o processo de identificação, embora presente, parece ter outro contorno. Enquanto Casimiro Lopes potencializa o traço comum, Madalena complementa o fazendeiro naquilo que lhe falta, quer no plano físico quer no econômico quer no psíquico. Fisicamente, Paulo Honório tem "nariz enorme, boca enorme, dedos enormes" (São Bernardo, p. 190); enquanto Madalena, com "cabecinha, mãozinhas" (São Bernardo, p. 65), se configura "miudinha, fraquinha" (São Bernardo, p. 67). No aspecto econômico, os termos do casamento são claros, um entra com o capital e o outro com a instrução:

- O seu oferecimento é vantajoso para mim, seu Paulo Honório, murmurou Madalena. Muito vantajoso. Mas é preciso refletir. De qualquer maneira, estou agradecida ao senhor, ouviu? A verdade é que sou pobre como Job, entende?

- Não fale assim, menina. E a instrução, a sua pessoa, isso não vale nada? Quer que lhe diga? Se chegarmos a acordo, quem faz um negócio supimpa sou eu. (São Bernardo, p. 89)

No plano psíquico, o proprietário de São Bernardo se apropria do traço desejado, a educação formal, que não pôde ser desenvolvido em nome da construção de seu patrimônio, conforme afirma: "Ocupado com esses empreendimentos [a fazenda] não alcancei a ciência de João Nogueira nem as tolices de Gondim" (São Bernardo, p. 9). Portanto, mais uma vez, temos o processo de incorporação dos traços do outro, e, se os atributos de Casimiro Lopes permitem a expansão dos limites da fazenda, os de Madalena propiciam a ampliação dos limites internos do protagonista.

${ }^{181}$ Telma de Barros Correia, op. cit., p. 268. 
O procedimento aqui descrito aparece explicitamente em uma crônica de Graciliano Ramos intitulada "Um homem notável". O protagonista, que prospera graças a duas qualidades ("branco e analfabeto"), apropria-se de outra ao se casar com uma secretária diplomada pela escola normal: "Casou - e todas as dificuldades se sumiram. Para bem dizer, tornou-se proprietário dos conhecimentos da mulher. Considerou-os coisas dele, como o brilhante, a cadeia, o relógio, os móveis, os semoventes e os imóveis" (Viventes das Alagoas, p. 111).

Ao projetar seu traço, reprimido ou não, em outra pessoa, o dono de São Bernardo passa a ter uma atitude ambivalente: de amor, porque passa a conviver com a qualidade desejada e aferir as vantagens da convivência; e de ódio, pois teme ser ludibriado. A situação exige, portanto, vigilância constante do outro. Com Casimiro, Paulo Honório conhece o prazer de não ser contrariado; com Madalena, a frustração de viver com alguém independente.

Incapaz de tomar uma atitude sem autorização, o jagunço traz tranqüilidade ao fazendeiro, que interpreta essa obediência cega como fidelidade: "Gosto dele. É corajoso, laça, rasteja, tem faro de cão e fidelidade de cão" (São Bernardo, p. 14). Madalena, ao contrário, dá mostras de iniciativa desde os primeiros momentos do casamento: examina documentos, conserta uma máquina de escrever emperrada, interessa-se pela saúde dos trabalhadores etc. Enquanto as ações trazem benefícios a Paulo Honório, não há recriminações, mas quando introduzem uma lógica contrária à adotada em São Bernardo, as desavenças se amiúdam.

Inicialmente o fazendeiro critica a aplicação do dinheiro, pois considera a ajuda a mestre Caetano, como quer Madalena, dinheiro perdido; depois entra em conflito acerca do valor do ordenado de Sr. Ribeiro - baixo, na opinião da mulher -; por fim, qualifica a compra de material didático, feita pela esposa, de despesa supérflua. Fica claro que a administração de Madalena representa uma ameaça, pois sua conduta contraria o princípio da rentabilidade, isto é, qualquer ação que não gere lucro é desnecessária e dispendiosa. Entretanto, ainda que discorde da esposa, a raiva se desloca para terceiros, a culpa ora é de dona Glória ora de Marciano.

No segundo momento, a situação se modifica: a raiva se concentra em Madalena, tanto a provocada por seus atos, quanto a decorrente de problemas da fazenda. Quando o volante e o dínamo enguiçam, Paulo Honório vê desperdício ${ }^{182}$ nos presentes dados pela esposa a Margarida e Rosa; depois, quando a Prefeitura suspende a compra de pedras, o desperdício vira roubo ${ }^{183}$ Curiosamente, quanto mais o protagonista persegue e responsabiliza Madalena, mais se sente perseguido e isolado. Imagina que os agregados conspiram contra sua pessoa:

Puxei uma cadeira e sentei-me longe deles [Madalena, Padilha, d. Glória e seu Ribeiro]. Era possível que a palestra não me interessasse, mas suspeitei que estivessem falando mal de mim [...]. Entretidos, animados. Conspiração. Talvez não fosse nada. Mas para quem, como eu, andava com a pulga atrás da orelha! Aborrecia. (São Bernardo, p. 121)

O desencontro com a administração dos bens, a perseguição e o sentimento de ser perseguido dão um salto tremendo, durante a festa em que o casal comemora dois anos de união, pois o desentendimento ideológico se transforma em ciúme. No início do capítulo, sob alegação de desvio de função, Paulo Honório repreende Padilha, porque está colhendo rosas, a pedido de Madalena. Depois, no escritório, o fazendeiro é assaltado por uma idéia que não

\footnotetext{
182 "Está visto que Madalena não tinha nada com o descaroçador e a serraria, mas naquele momento não refleti nisso: misturei tudo e a minha cólera aumentou. Uma cólera despropositada” (p. 120).

183 "Além de tudo vestido de seda para a Rosa, sapatos e lençóis para Margarida. Sem me consultar. Já viram descaramento assim? Um abuso, um roubo, positivamente um roubo” (p. 122).
} 
consegue determinar, mas olha com desconfiança para a mulher. Posteriormente, durante a festa, dá corpo à suspeita: Padilha e Madalena estão conluiados.

Certamente, não escapará ao leitor que o conluio aventado é de natureza ideológica, pois a desconfiança de Paulo Honório é de que Madalena e Padilha se uniram para pregar $o$ comunismo aos trabalhadores: "Sim senhor! Conluiada com o Padilha e tentando afastar os empregados sérios do bom caminho" (São Bernardo, p. 132). No entanto, por intermédio do significante rosa, o desencontro ideológico parece deslizar, sutilmente, para a esfera amorosa. A coincidência entre as flores colhidas por Padilha (rosas) e o nome da amante de Paulo Honório - Rosa - permite que tal deslizamento ocorra. Em outras palavras, o significante evoca uma traição e cria o elo entre o adultério realmente cometido pelo protagonista e outro apenas imaginado.

Do ponto de vista psíquico, o procedimento não é raro, porque, segundo Freud, há três camadas ou graus de ciúme: o normal ou competitivo, o projetado e o delirante. Para o autor: "O ciúme da segunda camada, o ciúme projetado, deriva-se, tanto nos homens quanto nas mulheres, de sua própria infidelidade concreta na vida real ou de impulsos no sentido dela que sucumbiram à repressão". ${ }^{184}$

No romance, parece estarmos diante do ciúme projetado, pois, apoiado no significante - Rosa -, Paulo Honório inverte a situação de adúltero à vítima de adultério. Não é gratuito que, no capítulo 31, em que Madalena se mata, o protagonista informa que a página da carta que voara para o jardim, ${ }^{185}$ "prova da traição" da esposa, estava em sua carteira entre "faturas de cimento e orações contra maleitas que a Rosa anos atrás me havia oferecido" (São Bernardo, p. 169). Em outras palavras, a página tinha por destinatário o próprio fazendeiro, o que configura o adultério imaginado; em contrapartida, a mesma página era guardada entre as orações oferecidas por Rosa, o que remete ao adultério real.

À situação acrescem-se outros dois elementos que, na verdade, a precedem: tanto Madalena quanto Paulo Honório trazem, em seus nomes, cargas significativas que remetem à questão da honra. A primeira é associada popularmente à prostituta ou "pecadora" de quem Cristo exorciza sete demônios; ${ }^{186}$ e o segundo significa etimologicamente "pouca honra". ${ }^{187}$ Tecida a complementaridade, por intermédio dos significantes, o fazendeiro dá vazão ao processo de ciúme.

Confio em mim. Mas exagerei os olhos bonitos do Nogueira, a roupa bem-feita, a voz insinuante. Pensei nos meus oitenta e nove quilos, neste rosto vermelho de sobrancelhas espessas. Cruzei descontente as mãos enormes, cabeludas, endurecidas em muitos anos de lavoura. Misturei tudo ao materialismo e ao comunismo de Madalena - e comecei a sentir ciúmes. (São Bernardo, p. 133)

\footnotetext{
${ }^{184}$ Sigmund Freud, "Alguns mecanismos neuróticos no ciúme, na paranóia e no homossexualismo", in Obras psicológicas completas, Rio de Janeiro, Imago, 1996, vol. XVIII, p. 238.

${ }^{185}$ O protagonista pergunta à esposa: “- Mas a carta? Madalena apanhou o papel, dobrou-o, entregou-mo: // - O resto está no escritório, na minha banca. Provavelmente esta folha voou para o jardim quando eu escrevi” (p. 163).

${ }^{186}$ Segundo a Legenda áurea: "Maria, cognominada Madalena por causa do castelo de Magdala, nasceu em família muito digna, descendente de reis. [...] mas como a abundância é acompanhada pela volúpia, quanto mais percebia o esplendor de suas riquezas e de sua beleza mais submergia o corpo na volúpia, de modo que logo deixou de ser chamada pelo nome, e sim por 'a pecadora' [...]. O Senhor concedeu imensos benefícios a Maria Madalena e distinguiu-a com sinais de predileção: expulsou dela sete demônios, inflamou-a totalmente de amor por Ele, tornou-se íntimo dela, passou a ser seu hóspede, fez dela a encarregada de cuidar de suas viagens e sempre a defendeu com doçura, fosse diante do fariseu [Simão] que, comparando-a com a irmã, tachava-a de imunda e preguiçosa, fosse diante de Judas, que a chamava de dissipadora" (Jacopo de Varazze. Legenda áurea: vidas de santos, São Paulo, Companhia das Letras, 2003, p. 544).

${ }^{187}$ Em latim paulö (paullö), pouco e honor (honös), -öris, honra, dignidade (Ernesto Faria, Dicionário escolar latino-português, Rio de Janeiro, FAE, 1988, pp. 254 e 393).
} 
Convém assinalar que os predicados de Nogueira, cujo conjunto denota o trabalho intelectual longe da lavoura, incomodam o narrador tanto quanto o materialismo $e o$ comunismo de Madalena. Embora explicite apenas os traços físicos, o leitor recorda que o advogado está associado especialmente ao universo cultural, uma vez que domina aspectos gramaticais da língua ${ }^{188}$ e possui "a ciência, não alcançada" por Paulo Honório. Desse modo, o conflito do casal se acirra sem que o protagonista, antigo guia de cego, veja sua responsabilidade na emergência do sentimento que o atormenta.

Cego pelo ciúme, o fazendeiro intensifica a perseguição à esposa. Inicialmente, em suas fantasias, imagina que Madalena se interessa por Dr. Nogueira, Padilha, Gondim, Dr. Magalhães, enfim, por todos que tiveram acesso à educação formal, justamente o que lhe falta. Depois, atribui a pretensa infidelidade à formação na escola normal e à desenvoltura da companheira. Cabe sublinhar que o atributo que justificara a união do casal passa a ser agora o motivo alegado para a separação. Por fim, chega à conclusão de que, embora partilhem o mesmo espaço, não conhece a esposa: “"-O senhor conhece a mulher que possui'. Conhecia nada! Era justamente o que me tirava o apetite. Viver com uma pessoa na mesma casa, comendo na mesma mesa, dormindo na mesma cama, e perceber ao cabo de anos que ela é uma estranha!" (São Bernardo, p. 150).

Não é gratuito que a perseguição se torne mais intensa, após essa conclusão, basta lembrar que, etimologicamente, estranho (extraneus, -a) significa exterior, de fora, ou o estrangeiro, ou seja, aquilo que permanece fora de controle, e, psicanaliticamente, estranho pode ser pensado como "aquela categoria do assustador que remete ao que é conhecido, de velho, e há muito familiar". ${ }^{89}$ Logo, frustrado em seu desejo de controlar o objeto que escapa recorrentemente e ameaçado por algo que o assusta, Paulo Honório passa a desconfiar de todos.

Para o dono de São Bernardo a conspiração não tem fim: começa com dona Glória, prossegue com Margarida, depois Tubarão, o cão de guarda, até mesmo seus próprios olhos e ouvidos o enganam. Dessa forma, o fazendeiro, que experimentara a tranqüilidade com Casemiro Lopes, sofre os efeitos do medo persecutório, proveniente do estado de frustração com Madalena. E assim como "reprimiu" o traço desejado, a escrita, em nome da construção do patrimônio, a perseguição só se encerra com a eliminação do objeto no qual projetou a qualidade aspirada, quer com uma separação apenas no plano simbólico, quer acompanhada por um afastamento na realidade. A segunda alternativa é a que acontece: exausta, Madalena põe fim à sua vida.

Com a morte da esposa, o protagonista inicia o processo de luto, e, apesar dos esforços para retomar o antigo ritmo de trabalho, sua energia se esvai rapidamente. A partida de Dona Glória, Sr. Ribeiro, Padilha acentua o sentimento de vazio. Finalmente, quando tudo parece perdido, decide de forma inesperada compor um livro. Em aparência gratuita, a idéia pode ser compreendida se lembrarmos do que Freud ensina sobre a diferença entre luto e melancolia. Embora ambos estejam relacionados à perda efetiva de um objeto amado, na melancolia, há perturbação da auto-estima e é possível supor que, "mesmo que o paciente esteja cônscio da perda que deu origem à sua melancolia, sabe apenas quem ele perdeu, mas não o que perdeu nesse alguém". ${ }^{190}$ Passados dois anos da morte da mulher, o proprietário de São Bernardo parece ter intuído "o que perdeu", pois resolve penetrar o espaço de Madalena, o território das letras, e inicia a elaboração de seu livro de memórias. No processo, explicita o desejo de incorporar o atributo ligado à mulher: "Ora vejam. Se eu possuísse metade da instrução de

\footnotetext{
188 "Dirigi-me a alguns amigos, e quase todos consentiram de boa vontade em contribuir para o desenvolvimento das letras nacionais. Padre Silvestre ficaria com a parte moral e as citações latinas: João Nogueira aceitou a pontuação, a ortografia e a sintaxe [...]” (p. 3).

${ }^{189}$ Sigmund Freud, "O estranho", in Obras psicológicas completas, Rio de Janeiro, Imago, 1996, vol. XVII, p. 238.

${ }^{190}$ Idem, "Luto e melancolia", in Obras psicológicas completas, Rio de Janeiro: Imago, 1996, vol. XIV, p. 251.
} 
Madalena, encoivarava isto brincando. Reconheço finalmente que aquela papelada tinha préstimo" (São Bernardo, p. 9).

Escrito aparentemente para imortalizar o perfil da esposa e simbolicamente para incorporá-lo, o livro cumpre sua função assim que é concluído, mas o resultado não anima o narrador. Não é para menos: a posse do território alheio, "o que perdeu" em Madalena, não traz a plenitude imaginada; ao contrário, impõe o confronto com a falta, elemento constitutivo do psiquismo. Mais uma vez o vazio o invade.

Nessa perspectiva, é possível pensar que elementos tais como a escolha de Madalena, as bases da união do casal, a emergência do ciúme, a necessidade de escrever o livro e o ressentimento do protagonista estão articulados, revelando momentos diferentes do mesmo funcionamento psíquico - busca, conquista e domínio do traço cobiçado. A essa hipótese se soma outra que talvez jogue luz sobre a intrigante situação de Madalena ocupar a maior parte dos capítulos da narrativa. Apesar das sucessivas tentativas, a apropriação desejada não se consolida, por motivos distintos. Por um lado, o pacto firmado em que Paulo Honório entra com a fortuna e a noiva com a instrução não se sustenta porque a esposa, diferente do jagunço, não se subordina aos desmandos do marido. Sofre intensa perseguição até que desiste e se mata, impedindo, desta maneira, que a projeção prossiga. Por outro lado, a experiência de ele próprio penetrar o território das letras - com o intuito de incorporar "o que perdeu" deságua em uma situação sem saída. Portanto, o fazendeiro traça o perfil da mulher com apuro e reserva-lhe tanto espaço no livro de memórias, porque, entre outras razões, pretende compreender o malogro de sua busca.

Além disso, é curioso notar que Paulo Honório antes de concluir seu livro sonha com um lobisomem: "Julgo que delirei e sonhei com atoleiros, rios cheios e uma figura de lobisomem" (São Bernardo, p. 191). Ainda que se possa associar o estado emocional do fazendeiro à licantropia, já que há registros históricos nesse sentido, ${ }^{191}$ parece-nos, entretanto, que, na economia da obra, o sonho pode ser lido de outra maneira. O lobisomem pode expressar o desejo de reunir em uma só pessoa - o latifundiário - dois traços contraditórios: a animalização, marca do violento Casimiro Lopes, e a humanização, aspecto associado a Madalena.

A idéia ganha vulto se nos lembrarmos do mito que remonta à tradição grega. Conforme uma das versões, Licáon, rei da Arcádia, recebe Zeus como hóspede e lhe oferece carne humana, para verificar se era um deus ou um simples mortal. Posto à prova, Jove não perdoa e o transforma em lobo. Na apresentação de Ovídio, o mito pode ser lido como advertência à possibilidade de o homem perder a condição privilegiada (criado com "elevado semblante, para que olhasse para o céu") em virtude de seus erros e se igualar à situação dos outros animais ("de rosto baixo, inclinado para a terra"). Embora sofra adaptações no tempo e espaço, ${ }^{192}$ a idéia de reduzir os traços civilizados em favor dos ligados à natureza parece ressurgir no romance de Graciliano para representar o embrutecimento de Paulo Honório, que, durante o processo de se tornar um burguês, vai se transformando cada vez mais em lobo do próprio homem.

A aliança com Casimiro Lopes propicia que a dimensão animalesca se desenvolva, pois o protagonista, ao somar sua própria violência à do capataz, consegue viabilizar seus

\footnotetext{
${ }^{191}$ Segundo Fédida, "a antiga psiquiatria contava-nos o caso de doentes melancólicos que eram levados por seu delírio a acreditar-se [...] ou ainda de metamorfosearem-se em lobisomens (o que era designado de licantropia) (Pierre Fédida, Depressão, São Paulo, Escuta, 1999, p. 69). Câmara Cascudo acrescenta a seguinte informação: "Durante o século XVI os Loup-garou multiplicaram-se em França [...]. Jaime I da Inglaterra, equiparando-os aos feiticeiros, condenava-os sem cessar. O erudito soberano, autor de um livro sobre a 'Demonologia', explicava o 'werwolf' como resultado de superabundância de melancolia" (Luís da Câmara Cascudo, Geografia dos mitos brasileiros, São Paulo, Global, 2002, p. 178).

${ }^{192}$ Segundo Câmara Cascudo, a versão trazida pelo colonizador português identifica a predestinação ou o incesto como motivo da licantropia, enquanto a adaptação nordestina acrescenta a ancilostomíase e o paludismo (Idem, ibidem, p. 179-90).
} 
projetos econômicos: acumula seu primeiro capital no sertão, compra São Bernardo e expande os limites da fazenda. $\mathrm{O}$ aspecto selvagem, nas mãos do autor, aparece na representação do contexto social. A unidade entre o jagunço e o fazendeiro, e entre este e as personalidades históricas evidenciam aspectos do capitalismo no Brasil e permitem que o leitor apreenda a face "cangaceira" de nosso sistema econômico.

Ademais, o lobisomem é um ser dividido, mas que constitui uma nova unidade, e talvez aí encontremos outro elemento a emergir na narrativa do escritor, quer no âmbito individual quer na representação de aspectos do sistema social. No plano subjetivo, o fazendeiro aspira à unidade de conciliar num só corpo dois desejos antagônicos: o de mercantilizar seu entorno e o de não se desumanizar. No plano social, evoca, de um lado, a animalização promovida pelo "capitalismo cangaceiro", tanto naquele que produz riqueza quanto naquele que dela se apropria; e, de outro lado, a resistência à lógica mercantil, as atitudes humanitárias e humanizadoras. É necessário sublinhar que a busca ambicionada tanto numa como noutra dimensão está fadada ao fracasso. No primeiro plano, a idéia de completude ou de restabelecimento da unidade perdida só pode subsistir na fantasia, já que é impossível superar a cisão fundadora do homem. No segundo plano, é inexeqüível conciliar capitalismo e humanismo, conforme já vimos, em particular, nas passagens em que Madalena procura introduzir uma dinâmica menos perversa à lógica dominante em São Bernardo.

Além do lobisomem, outra imagem sugere concentrar mais de uma dimensão, possibilitando esclarecer uma situação que à primeira vista se apresentou paradoxal, ou seja, o título da obra. São Bernardo - espaço físico - dá mostras de guardar analogia com o espaço interno da personagem central. Ao trazer para o interior da fazenda Casimiro Lopes, Madalena e até pessoas que não se afinam com seu projeto econômico, esse modus operandi do narrador revela a disposição de incorporar algum traço ambicionado. Outrossim, com a morte da esposa, o fazendeiro não consegue recuperar o antigo ritmo de trabalho e sua disposição se esvai ao mesmo tempo em que os agregados partem. Os limites de sua propriedade, que se ampliam com Casimiro, são ameaçados com a partida daqueles com quem convive. Em suma, São Bernardo parece condensar o espaço onde o protagonista reúne os traços que admira, por um lado, e o lugar onde concentra suas realizações econômicas, por outro.

Desse modo, Paulo Honório parece se orientar por uma só idéia, a apropriação, quer do traço quer do trabalho do outro. A síntese denota a habilidade do autor, já que, em suas mãos, a lógica do aparelho psíquico não contraria a dos interesses econômicos; ao contrário, acentua. Portanto, não é demasiado sublinhar sua engenhosidade em sintetizar, por intermédio de imagens alicerçadas ou não na tradição literária, aspectos complexos do funcionamento psíquico e social. Por se tratar de um universo em que toda palavra foi transformada em uma encruzilhada de saberes, é que São Bernardo, visto no conjunto ou nas filigranas, surpreende a cada nova leitura. 